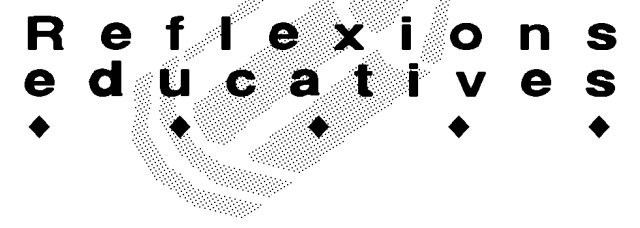

\title{
AFRONTAR EL REPTE DE LES SOCIETATS HETEROGÈNIES: ELEMENTS DE REFLEXIÓ PER A LA PRÀCTICA EDUCATIVA
}

\author{
Arantza del Valle Gómez. Àrea de Psicologia Evolutiva i de l'Educació. Universitat de Girona
}

\section{La societat heterogènia, un repte del segle xxI}

La majoria de les societats occidentals són heterogènies des del punt de vista nacional i/o cultural (per exemple, el Canadà, els Estats Units, el Regne Unit, Suïssa, Espanya, etc.). Aquesta heterogeneïtat crea nombroses situacions en les quals les relacions entre les persones que pertanyen a diferents grups socials, culturals o nacionals no són un assumpte fàcil. Aquesta situació ha generat un interès renovat per l'estudi del desenvolupament dels processos que orienten i defineixen aquestes relacions (MONREAL, 2007).

Aquest article se centra en tres premisses bàsiques: (a) Per entendre els processos psicològics és necessari entendre els processos implicats en la seva gènesi i desenvolupament. (b) Per estudiar el procés evolutiu relacionat amb la construcció de la identitat social (nacional, cultural, etc.) no és suficient estudiar-lo en el context social, sinó que cal considerar-ne la construcció social. Per aquest motiu, teories sobre com es construeixen els objectes socials i els seus significats vertebren aquest article. (c) Les nenes i els nens interactuen amb els altres: des que neixen estan subjectes a regulacions externes que organitzen i ordenen les seves vides, i des d'aquest moment comencen a construir les normes implícites que governen aquestes regularitats. Però aquest procés no és passiu: no implica que els infants siguin simples receptors de les influències socials, sinó que el procés de socialització és un procés actiu, en què a partir d'unes regles i normes socials els nens i les nenes construeixen valors socials i morals.

En el desenvolupament social de la infància, les interaccions socials transmeten, construeixen, mantenen i transformen les identitats socials dels infants. Aquestes interaccions socials són relacions directes cara a cara i també derivades de l'estructura politicoeconòmica. Per tant, la construcció de la pertinença a un grup social, nacional, cultural, ètnic, etc., la identitat social, és un procés complex en el qual tots els elements que constitueixen l'entorn social de la infància (creences, emocions, valors, història, pràctiques socials, coneixement, etc.) sobre el propi grup $i$ els altres estan entrellaçats.
Nombroses investigacions ens mostren com el desenvolupament de la identitat social exhibeix una variabilitat considerable com a funció de la situació sociocultural específica (BARRET et al., 2006). Aquesta variabilitat no pot ser explicada amb teories que postulen que els nens $i$ les nenes es desenvolupen de forma similar $i$ independentment del seu context sociocultural específic. És necessari fer aproximacions que tinguin en compte les aportacions sociopsicològiques (MOSCOVICI, 1988; FAR i MOSCOVICI, 1984; BREAKWELL i CANTER, 1993), que postulen que les persones difereixen segons el context sociocultural específic.

\section{La complexitat de les relacions intergrupals: una realitat a les escoles}

La societat actual és, per definició, un context heterogeni on coexisteixen distintes cultures dins d'una mateixa comunitat política, qualsevol que en sigui l'origen (nacionalitats, minories, immigrants, etc.).

Per a la institució escolar actual, aquesta situació és altament complexa donada la gran diversitat de grups socialment rellevants que trobem a l'aula, davant de la qual està desarmada, confosa $\mathrm{i}$, per dir-ho suaument, poc preparada. Els professionals de l'educació se situen davant de qüestions que van més enllà de les relacions personals de/amb els alumnes, els quals impliquen les interaccions entre els membres de grups socials diferents i segueixen processos que han de conèixer i marcs de referència socials i culturals sobre els quals és necessari reflexionar. L'educació en una societat heterogènia, en l'àmbit social, cultural i nacional, necessita crear iniciatives per millorar la comprensió entre els grups i reduir els estereotips i el prejudicis.

Nombroses investigacions, algunes ja clàssiques com les de Goodman (1952) i Clark i Clark (1947), demostren que els infants diferencien i s'identifiquen amb categories socials rellevants en el context de desenvolupament (per exemple, sexe, raça, nacionalitat, etc.) des d'edats tan primerenques com els tres anys. Aquesta identificació porta associada creences i sentiments sobre el propi grup i els altres sense que sigui necessari que 


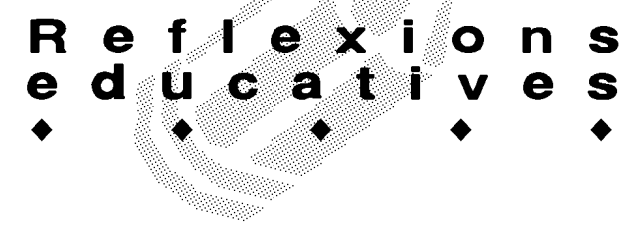

els infants tinguin cap coneixement formal sobre les categories (TAJFEL, 1984). És a dir, s'identifiquen i desenvolupen sentiments com a nens o nenes, abans de tenir coneixement sobre les diferències sexuals, les races i la realitat política i nacional del nostre país. Seria, per tant, un error abordar una qüestió com aquesta reduint-la, limitant-la o supeditant-la a l'adquisició de coneixements entorn als diferents grups.

Des del naixement els nens i les nenes obtenen influències de l'entorn més pròxim i adquireixen creences, actituds i valors envers les categories socials rellevants en el context. Simultàniament, reben missatges estereotipats dels contes, llibres, televisió, pel-lícules, revistes i diaris. Per exemple, el fet que certes persones no apareguin en els mitjans de comunicació (grups racials ètnics, gent gran o disminuïts) o que només apareguin associats a un problema o situació conflictiva, transmet als nens el missatge que aquests grups tenen menys valor o un valor negatiu, des d'un punt de vista social. Aquest procés varia amb l'edat i amb el context familiar, polític, cultural i lingüístic en què els infants es desenvolupen. Les nenes i el nens pensen sobre la vida quotidiana, sobre les característiques del seu ambient, integren la informació que circula en el seu context social i construeixen un món que no sempre coincideix amb el dels adults, però que els ajuda a comunicar i a entendre les situacions en què es troben immersos i a adquirir coneixements sobre el propi grup i els altres. D'aquesta manera, des d'edats molt primerenques, ja poden utilitzar categories socials de diferent índole, de forma molt semblant a la dels adults, encara que amb significats diferents.

Investigadors com Aboud (1988), Del Valle (1998), Barret (2006) ens mostren com nens d'entre cinc i set anys ja assenyalen, en la valoració sobre el seu grup i els altres, fenòmens com el favoritisme, l'homogeneïtzació, els estereotips i els prejudicis, els quals fins fa poc estaven reservats als adults. La direcció de les preferències infantils entre els diferents grups depèn de la situació social de cada grup en una societat més àmplia.

L'explicació més òbvia de l'aparició dels estereotips i prejudicis en els nens és que s'adquireixen a través de la socialització directa amb els seus pares i amb altres fonts, com són la influència del grup dels progenitors i els canals habituals de transmissió cultural: contes, llibres i, sobretot, la televisió. Desgraciadament la veritat no és tan simple. Aquesta transmissió, encara que innegable, rarament té una direcció clara o un efecte nítid. L'adquisició del prejudici és un procés més dinàmic: una interacció entre el desenvolupament de les capacitats sociocognitives del nen i l'entorn socialment estructurat al qual s'ha d'enfrontar. És a dir, el desenvolupament del pensament prejudicial dels infants apunta cap a un procés de desenvolupament dinàmic on el nen busca activament comprendre, avaluar i controlar el món social amb els recursos cognitius, normalment limitats, que té al seu abast. Els biaixos i les preferències no són el resultat d'adoctrinaments passius, sinó del creixement natural d'una interacció entre el món i els processos psicològics de categorització, identificació i comparació en la ment dels nostres infants.

Per treballar de forma eficaç pel canvi de les actituds dels més joves es necessiten més elements que la informació sobre els altres grups, nacions, culturals, comunitats ètniques, etc. Es necessita estudiar les arrels dels estereotips i els prejudicis, prendre consciència dels seus esquemes i analitzar-ne l'origen. S'ha d'aprendre a reduir els estereotips, desenvolupar capacitats per evitar-los i eliminar els prejudicis o almenys incrementar la consciència per saber quan s'està emetent un judici esbiaixat.

\section{La modificació dels estereotips i la reducció del pre- judici en l'àmbit escolar}

Estereotipar és atribuir a una persona alguna característica que es considera compartida per tots o quasi tots els membres del seu grup. Els estereotips són creences que atribueixen característiques als membres d'un grup pel fet de ser-ne membre. No han de ser necessàriament ni positius ni negatius; hi ha estereotips positius i estereotips negatius. Els estereotips:

- Són part del funcionament cognitiu de les persones. Tothom té estereotips sobre grups socials rellevants en el context.

- Estan immersos en la cultura en què hem crescut i es transmeten i reprodueixen des de les formes socioculturals a l'ús, a través de la socialització en la família, l'escola, els llibres, la televisió, els mitjans de comunicació, etc. La societat és una construcció dinàmica i, per tant, els estereotips també canvien a partir del clima normatiu de la societat i el desig social.

- Deriven, encara que vagament, de la realitat social. Això no vol dir que siguin certs, sinó que representen models de comportament que caracteritzen un grup. Tenen un "aire de versemblança". Són una sobrerepresentació del context social.

- Regulen les relacions interpersonals i no es deriven del sistema cognitiu sinó del sistema emocional; moltes vegades ajuden a justificar la desigualtat social o accions determinades.

- Poden basar-se en la baixa freqüència. El que es considera "rar" pot donar lloc a l'estereotip. Una característica $X$ poc freqüent entre el grup $Y$ pot 


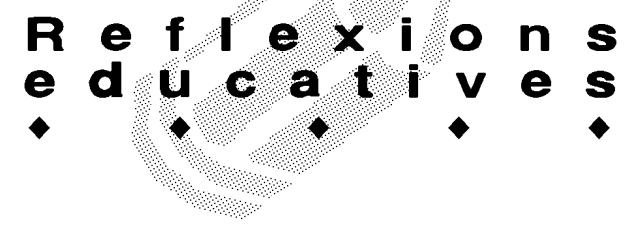

fer que es generi un estereotip determinat sobre els membres del grup $Z$. Per exemple, en un país predominantment habitat per persones de raça blanca es recordaran més ràpidament les conductes antisocials, encara que siguin relativament escasses, comeses per una persona de raça negra que per una de raça blanca.

- Poden ser molt útils perquè simplifiquen la informació complexa i permeten percebre algunes coses molt ràpidament, alliberant recursos cognitius per concentrar-los en altres aspectes (encara que aquestes expectatives estereotípiques poden portar-nos a errors, perquè esbiaixen la recerca d'informació i la nostra receptivitat cap a aquesta).

- Afecten el judici inclús quan la informació de les característiques individuals de la persona jutjada està disponible. Encara que tinguem informació disponible per valorar adequadament una persona, l'estereotip que tenim del grup social on es classifica pot desviar el nostre judici.

- Poden, per si mateixos, crear les condicions en les quals la prova confirmatòria està disponible més ràpidament. Actuen com una predicció que s'autocompleix.

- Influeixen en les nostres expectatives de futur i també en la reconstrucció dels records. Es recorden millor les situacions, fets i comportaments que confirmen l'estereotip que les que no hi coincideixen. Els efectes selectius dels estereotips sobre la memòria es donen fins i tot en condicions molt senzilles.
- Influeixen en les explicacions de les persones sobre els fets socials. Les persones tendeixen a atribuir comportaments coherents amb l'estereotip. Per exemple, si una part de l'estereotip sobre el grup $X$ es basa en la naturalesa violenta de les persones que l'integren i veiem una situació en què un membre del grup $X$ té una baralla, atribuirem aquest comportament a la seva naturalesa violenta abans de conèixer la situació en què està immers.

D'altra banda, el prejudici és un conjunt generalitzat d'estereotips, dotat d'un alt grau de consistència que inclou respostes emocionals, una creença en unes característiques distintives associades als grups socials rellevants i una avaluació dels trets típics.

Podem dir que els prejudicis:

- Són uns judicis previs.

- Impliquen una avaluació -una infraavaluació o supraavaluació, segons els casos-que suposa una càrrega afectiva.

- Són assumits per qui els formula, i per tant són creences que tenen la particularitat de ser en gran mesura immunes a les informacions noves que les posen en qüestió.

- Són socials, per tal com es refereixen a les persones com a membres de grups, afecten els seus comportaments i també les relacions tant internes com externes del grup.

La tendència dels éssers humans cap a una forma de pensar i uns comportaments amb estereotips i prejudicis mai no desapareixerà del tot, ja que les nostres

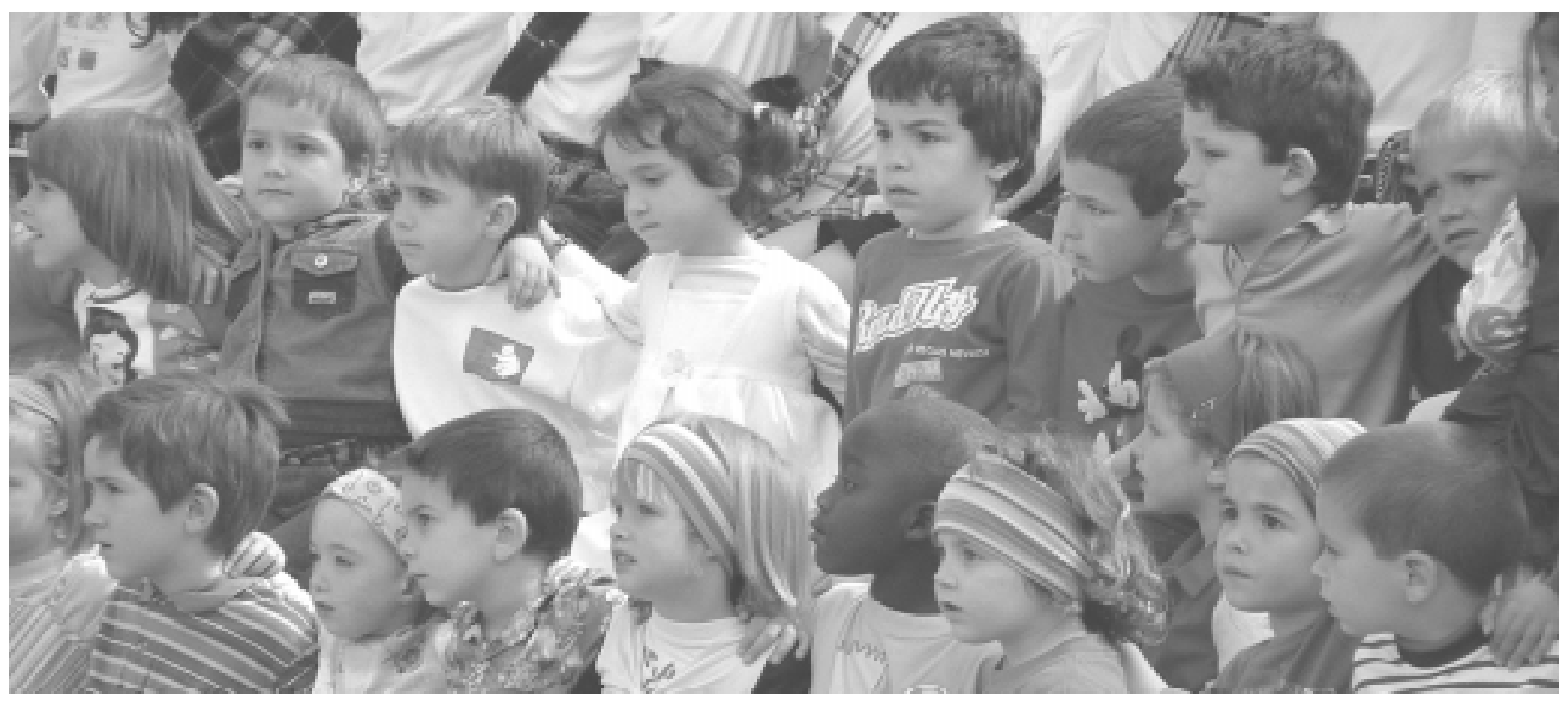




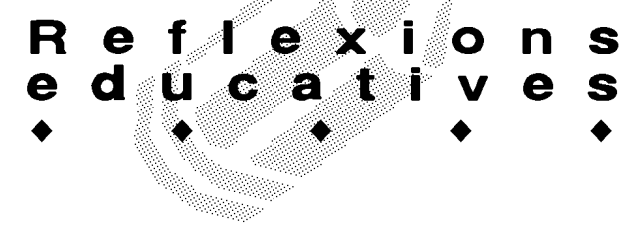

capacitats cognitives són limitades i la pertinença a grups diferents comporta importants motivacions socials inherents, ja que els estereotips i els prejudicis són com dreceres mentals que estalvien la feina d'investigar, conèixer i avaluar en profunditat cada persona que coneixem. En situacions d'alta ocupació cognitiva (situacions d'estrès, de simultaneïtat de tasques, etc.), en les quals estem distrets del judici que emetem, es produirà més estereotipatge sobre les categories socials que siguin rellevants.

Els estats d'ànim també afecten els estereotips. Situacions d'emocions intenses poden augmentar la probabilitat del judici estereotipat. La interacció i/o el treball amb membres d'altres grups diferents del propi poden ser, i en general són, fets provocadors d'ansietat, a causa de conflictes preexistents o de la tensió com a producte de la ignorància, el desconcert o la falsa percepció.

Però hi ha poderoses intervencions socials que redueixen la intensitat del prejudici i poden controlar-ne els pitjors efectes.

Una de les falses idees més esteses amb relació a aquest tema és que la millor forma de reduir la tensió i l'hostilitat entre grups es posant-los en contacte de diferents maneres. D'una forma ingènua i completament desinformada, durant els anys seixanta i setanta, en escoles dels Estats Units, la Gran Bretanya i el Canadà, entre d'altres, es van proposar models d'integració basats únicament en el contacte entre nens de diferents grups socials, i van esperar que això reduís els comportaments socials negatius, és a dir, les actituds prejudicades, els judicis esbiaixats i els comportaments hostils. Però aquest no és el cas. Quan dos grups es troben en contacte sorgeixen amb molta facilitat els biaixos endogrupals, que després resulten molt difícils de reduir. S'activen els processos de favoritisme del propi grup, I'homogeneïtzació dels altres, etc. Així doncs, el simple contacte entre els grups no és suficient per reduir els estereotips i els prejudicis intergrupals.

$\mathrm{Si}$ es volen reduir aquests efectes seriosament, els contactes intergrupals s'han de dissenyar tenint en compte certs aspectes:

- Els estereotips i prejudicis més resistents al canvi són els acceptats socialment.

- Els trets negatius dels estereotips són més fàcilment adquirits i més difícilment modificats que els trets positius. Mentre que uns quants exemples que contradiuen un tret positiu de l'estereotip fan que aquest es modifiqui, es necessiten molts exemples que contradiguin un tret negatiu per tan sols iniciar un canvi.

- Quan les persones s'enfronten a informació que s'oposa a l'estereotip, en general realitzen un sub- tipificació que afegeix heterogeneïtat a l'exogrup i aporta complexitat. Es construeixen subcategories dins del grup estereotipat que s'ajusten a les noves informacions, la famosa "excepció que confirma la regla”. Però la proliferació de subtipus, necessària per a una exposició a una àmplia gamma de contraexemples, fa que la categoria supraordenada original resulti molt menys útil. Per tant, l'estereotip global comença a fragmentar-se i es torna menys potent.

- D'altra banda, les relacions d'interdependència rebaixen l'ús dels estereotips. Si existeix una relació d'interdependència es tendeix a buscar informació específica sobre la persona i a confiar menys en l'estereotip de grup. Però aquests efectes es poden desorganitzar fàcilment per l'ocupació-distracció cognitiva.

Per maximitzar les possibilitats d'èxit d'un programa de modificació dels estereotips, reducció dels prejudicis i integració d'alumnes de diferents grups socials, s'han d'estructurar deliberadament les activitats en les quals participen, de forma que compleixin certes condicions:

- Han de produir-se dins un marc de suport social i institucional: han de ser proposades i introduïdes pel professorat amb el suport institucional de l'escola i la societat.

- Han de tenir un potencial de canvi: la freqüència, la durada i la proximitat han de ser suficients per permetre el desenvolupament de relacions significatives entre els membres dels grups implicats. Necessiten un grau alt d'interacció, estudiantestudiant, que permetrà incrementar el potencial de canvi del grup.

- Han de tenir lloc entre participants d'estatus social similar. Han de permetre una diferenciació clara de rols o ressaltar la importància de la contribució de cada membre al producte del grup en el seu conjunt, i han de donar, per tant, el mateix estatus a tots els membres del grup.

- Han d'estar basades en la cooperació, és a dir, que els diferents grups tinguin una relació d'interdependència per obtenir els objectius desitjats. La seva estructura ha d'orientar-se cap a una divisió del treball entre els estudiants, de tal forma que cadascú necessiti l'altre per aconseguir l'èxit en la tasca de grup (interdependència).

El mètode més comú per aconseguir la reducció dels prejudicis a l'escola és la utilització de grups d'aprenentatge cooperatius, on es barregin sexes, races i altres categories rellevants.

Tot això no implica que totes les tasques s'hagin de fer amb la mateixa estructura, cosa que seria pedagògi- 


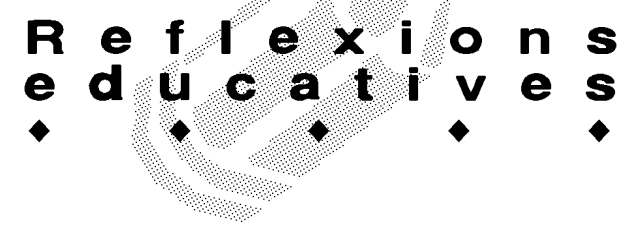

cament poc aconsellable, sinó que podem introduir variacions amb relació a:

- La competició. Es pot introduir la competició entre grups (cooperatius en el seu funcionament intern) si el que es vol és augmentar la cohesió i la simpatia dins dels grups d'aprenentatge heterogenis. Però aquesta estratègia implica que hi hagi grups perdedors entre els quals la cohesió i la simpatia intragrupal descendirà. Alguns estudis demostren que l'ús dels grups cooperatius en absència de competició dóna millors resultats en la reducció dels prejudicis.

- L'estructura de la tasca cooperativa vers la recompensa cooperativa. És possible fer que els alumnes treballin junts però que se'ls recompensi individualment, que treballin individualment però que se'ls recompensi conjuntament 0 , el que seria més habitual, combinar la tasca i les estructures de recompensa.

- El grau en què el professorat assigna als estudiants rols determinats dins d'un grup. És important assegurar-se la participació igual de tots els estudiants en l'activitat d'aprenentatge i contrarestar les expectatives prèvies pel que fa a la competència dels membres del grup minoritaris o amb menys avantatges.

Per potenciar el caràcter reductor dels prejudicis de les activitats escolars, a més de tenir les característiques necessàries per reduir els prejudicis, han de:

- Ser constants en el temps; no poden basar-se en activitats de poca durada anual.

- Presentar-se de forma transversal en més d'una assignatura.

- Permetre la generalització cognitiva de les actituds generades cap als membres d'un grup cooperatiu particular.

"El canvi d'actituds resultarà del contacte interracial cooperatiu només quan aquell contacte estigui acompanyat d'una influència suplementària que promogui el procés de generalització des del contacte favorable amb els individus fins a les actituds positives cap al grup del qual procedeix l'individu." (COOK, 1978. Pàg. 103).

Per potenciar la generalització cognitiva de les actituds positives generades a les activitats, es poden plantejar tres opcions:

a) Potenciar les interaccions a nivell interpersonal, on els participants tinguin oportunitat d'accedir a la informació de cada individu i es presti menys atenció a la informació basada en el grup de pertinença. El contacte interpersonal repetit tindrà com a resultat la falsedat dels estereotips pre- existents i permetrà la generalització de les actituds a noves situacions.

b) Recol-locar els límits de les categories i crear una categoria supraordenada on tots els participants pertanyin al mateix grup, i aprofitar el poder de la identitat grupal comuna per reduir les diferències intergrupals preexistents.

Aquests dos models, encara que funcionen, tenen com a particularitat que en potenciar la percepció de l'altre fan difícil que les actituds cap al seu grup de procedència canviïn.

c) Mantenir les diferències intergrupals, almenys amb un pes mínim, optimitzant simultàniament les diferents condicions del contacte intergrupal per reduir el prejudici. Cada participant actua com a representant del seu grup de pertinença. Si això s'organitza correctament, qualsevol canvi positiu es podrà generalitzar ràpidament a altres membres dels grups representats.

Aquest últim model té els avantatges següents:

- Com que no ignora les diferències, no corre el risc d'ignorar les desigualtats intergrupals existents i, per tant, de contribuir a la seva persistència.

- Com que es manté atent a les diferències de grup, fuig de les polítiques assimilacionistes, en les quals s'espera que els membres dels grups minoritaris es conformin en les normes i valors dels grups dominants.

- Com que reconeix la diversitat dels grups i els diferents sistemes de valors, adopta una estratègia pluralista, que proposa programes d'integració que capitalitzin de veritat les diferències de grup en benefici mutu dels membres dels grups majoritaris i minoritaris. Per exemple, amb el disseny de grups cooperatius, en què els participants puguin contribuir a la tasca del grup precisament perquè posseeixen una característica particular com a membre d'aquell grup.

Aquest model representa una perspectiva pluralista, que potencia la diversitat intergrupal i la diferenciació positiva i evita la regressió als models de prejudici habituals i destructius.

\section{Els professors com a promotors de les relacions in- tergrupals}

Des de la perspectiva pluralista del tractament de l'educació en contextos on la diversitat social, cultural i nacional és gran, el professorat educador, com altres vegades, es converteix en un element clau del procés:

- Ha de reconèixer el propis estereotips i prejudicis 


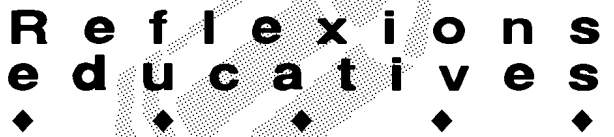

per poder reduir la possibilitat de la seva activació automàtica, i/o per ser capaç de rectificar si és que té un comportament no desitjat.

- Ha de reconèixer els estereotips i els prejudicis dels altres per presentar contrapunts.

- Ha de construir ponts de contacte entre els grups:

a) Organitzant les activitats i les dinàmiques de l'aula perquè intencionadament es generin espais per modificar els estereotips i reduir els prejudicis.

b) Establint lligams amb les famílies per potenciar que siguin un pont de trobada entre els diferents grups, on es reconeguin els comportaments estereotipats propis i els dels altres per presentar contrapunts.

c) Incidint en la societat per aconseguir que es generin models positius propers, per desenvolupar i implementar estratègies que permetin als joves de diferents grups socials (culturals, nacionals, ètnics, gènere, etc.) aconseguir un desenvolupament amb èxit, i que ajudin tothom a ser conscient dels seus estereotips i prejudicis i de les situacions que els activen.

Espero que aquest treball hagi servit per clarificar una qüestió que és complexa i planteja un repte quotidià a les escoles del nostre context més proper, i que, alhora, ajudi a plantejar iniciatives innovadores als responsables de l'educació dels nens i nenes de la nostra comunitat.

\section{Referències bibliogràfiques}

ABOUD, F. Children and Prejudice. Edit. Basil Blackwell. Oxford. 1988.

BARRET, M., et al. Children's knowledge, beliefs and feelings about people who belong to different national and state groups. Children's knowledge, beliefs and feelings about nations and national groups. Edit. Psychology Press. Hove, UK. 2006.

BREAKWELL, G. i CANTER, D. Empirical Approaches to Social Representation. Edit. Oxford University Press. Oxford. 1993.

CLARK, K. B. i CLARK, M. P. "Racial identification and preference in Negro children". Dins NEWCOMB, T. M. i HARTLEY, E. L. (Eds.), Readings in Social Psychology. Edit. Holt. New York. 1947.

COOK, S. W. Interpersonal and attitudinal outcomes in cooperating interracial groups. "Journal of Research and Development in Education», 12 (1978) 97-113.

DEL VALLE, A. The construction of national identity as a developmental process from childhood to adolescence in Catalonia. Universitat de Girona. 1998.

FARR, R. i MOSCOVICI, S. Social Representation. Edit. Cambridge University Press. Cambridge. 1984.

GOODMAN, M.E. Race Awareness in Young Children, Edit. Collier Mcmillian. New York. 1952.

MONREAL, P. "Globalización, identidad i multiculturalidad". Dins VILÀ, T. (Coord.). Lengua, interculturalidad e identidad. Edit. Documenta Universitaria. Girona. 2007.

$\mathrm{MOSCOVICl}$, S. Notes towards a description of social representations. «European Journal of Psychology», 18,3 (1988) 211-250

TAJFEL, H. The Social Dimension. Edit. University Press. Maison des Sciences de l'Homme. Cambridge. 1984.

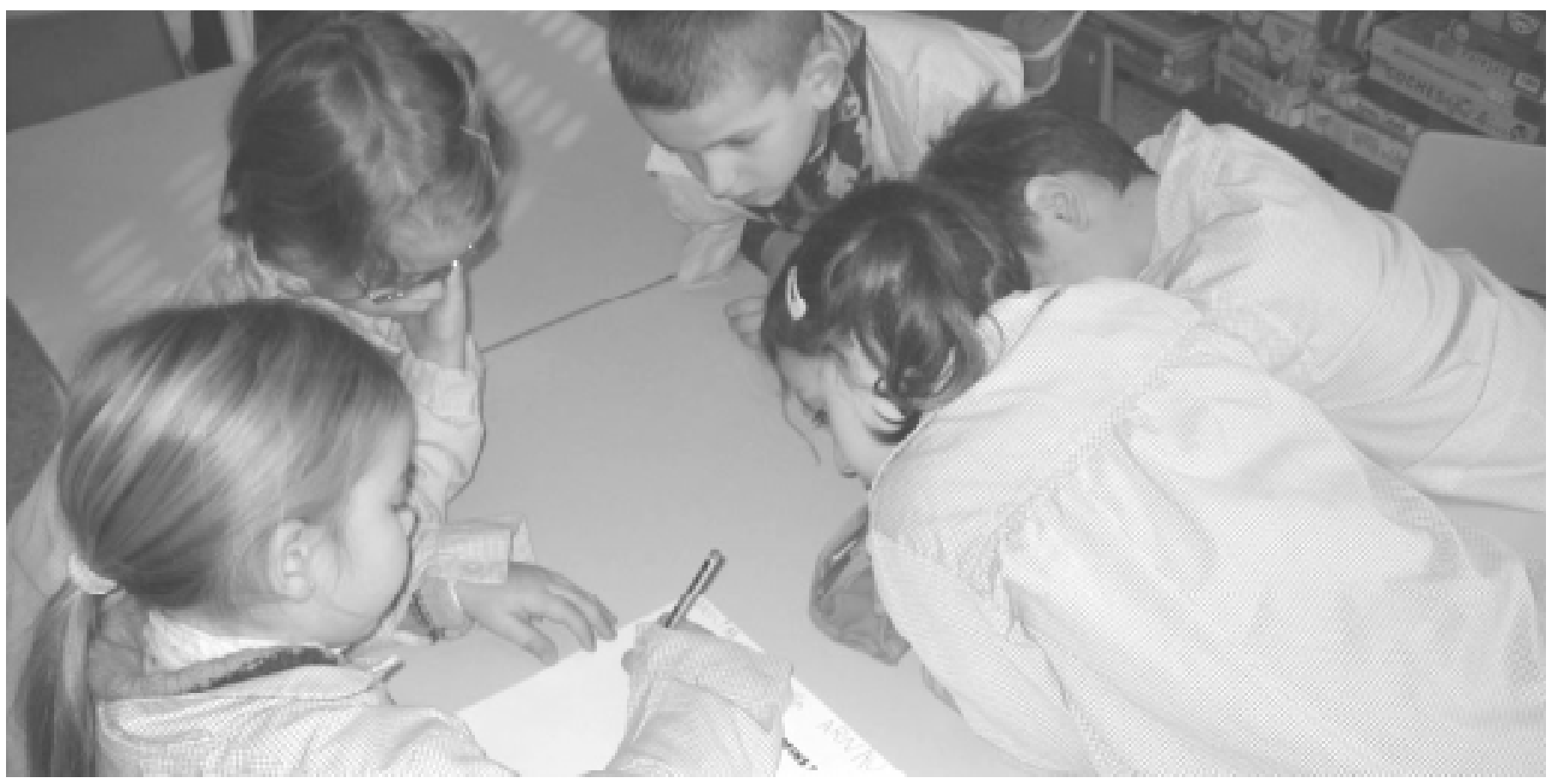

